\title{
An Accelerated Test Method of Simultaneous Carbonation and Chloride Ion Ingress: Durability of Silica Fume Concrete in Severe Environments
}

\author{
S. A. Ghahari, ${ }^{1,2}$ A. M. Ramezanianpour, ${ }^{3}$ A. A. Ramezanianpour, ${ }^{2}$ and M. Esmaeili ${ }^{4}$ \\ ${ }^{1}$ Department of Civil and Environmental Engineering, Purdue University, West Lafayette, IN 47906, USA \\ ${ }^{2}$ Department of Civil and Environmental Engineering, Amirkabir University of Technology, P.O. Box 15875-4413, Tehran, Iran \\ ${ }^{3}$ Department of Civil Engineering, University of Tehran, P.O. Box 14155-6619, Tehran, Iran \\ ${ }^{4}$ Department of Railway Engineering, Iran University of Science and Technology, P.O. Box 16765-163, Tehran, Iran
}

Correspondence should be addressed to S. A. Ghahari; sghahari@purdue.edu

Received 4 November 2015; Revised 19 April 2016; Accepted 27 April 2016

Academic Editor: Seung-Jun Kwon

Copyright (c) 2016 S. A. Ghahari et al. This is an open access article distributed under the Creative Commons Attribution License, which permits unrestricted use, distribution, and reproduction in any medium, provided the original work is properly cited.

\begin{abstract}
The effects of simultaneous carbonation and chloride ion attack on mechanical characteristics and durability of concrete containing silica fume have been investigated through an accelerated test method. Specimens containing different amounts of silica fume were maintained in an apparatus in which carbon dioxide pressure and concentration and relative humidity were kept constant, and wetting and drying cycles in saline water were applied. Surface resistivity, sorptivity, $\mathrm{CO}_{2}$ consumption, and carbonation and chloride ion ingress depths measurements were taken. Phase change due to carbonation and chloride ion attack was monitored by $\mathrm{XRD}$ analysis, and microstructures and interfacial transition zones were studied by implementing SEM as well as mercury intrusion porosimetry. It was expected to have a synergistic effect in the tidal zone where simultaneous carbonation and chloride ion attack happen. However, the observed reduced surface resistivity, compared to specimens maintained in $\mathrm{CO}_{2}$ gas, could be due to the moisture that is available near the surface, hindering $\mathrm{CO}_{2}$ from penetrating into the pores of the specimens. Moreover, the porosity analysis of the specimens showed that the sample containing silica fume cured in the tidal zone had 50.1\% less total porosity than the plain cement paste cured in the same condition.
\end{abstract}

\section{Introduction}

Deterioration of exposed structures, especially the ones made with concrete, may occur due to freezing and thawing cycles, sulfate attack, carbonation, and chloride ion attack [1]. Carbonation in such areas can take place due to pollution and chloride ion attack takes place because of sea water and/or deicing salts. In order to increase the strength and durability of concrete, blended cements or supplementary cementitious materials; that is, fly ash, limestone, silica fume, and so forth, should be used. By using such materials, reduction of carbon dioxide emissions to the atmosphere from the high energy consuming Portland cement clinker production, which affect environment, cost of production, and use of natural resources, would be achievable.

Carbonation may cause corrosion in reinforced concrete structures by reducing the $\mathrm{pH}$ in the pore solution [1]. And it is widely known that the reduction in $\mathrm{pH}$ of the pore solution can cause a significant increase in the concentration of chloride ions in the pore solution [2]. By polymerizing silicate chains in $\mathrm{C}-\mathrm{S}-\mathrm{H}$, volume decreases and shrinkage happens as well [3]. Extensive research has been performed on the deleterious effects of carbonation on durability [4, 5] and pore structure [6]. The reactions that take place in concrete microstructures are as follows [7]:

$$
\begin{aligned}
& \mathrm{Ca}(\mathrm{OH})_{2}+\mathrm{CO}_{2} \longrightarrow \mathrm{CaCO}_{3}+\mathrm{H}_{2} \mathrm{O} \\
& \mathrm{C}-\mathrm{S}-\mathrm{H}+2 \mathrm{CO}_{2} \longrightarrow \mathrm{SiO}_{2}+2 \mathrm{CaCO}_{3}+\mathrm{H}_{2} \mathrm{O}
\end{aligned}
$$

By consumption of $(\mathrm{OH})^{-}$in reaction (1), the $\mathrm{pH}$ of the pore solution decreases, which leads to an increase in the rate of corrosion [8] and a decrease in overall porosity [7, 9]. Reduction in $\mathrm{pH}$ value leads to destruction of the protective 
passive film around steel reinforcement $[10,11]$, resulting in rebar corrosion and cracking [3]. In marine environments where $\mathrm{CO}_{2}$ is available, such as the cities that are located adjacent to free waters, reaction (5) takes place through which $\mathrm{CaCO}_{3}$ is produced:

$$
\begin{gathered}
\mathrm{CO}_{2}+\mathrm{H}_{2} \mathrm{O} \longrightarrow \mathrm{H}_{2} \mathrm{CO}_{3} \\
\mathrm{H}_{2} \mathrm{CO}_{3}+\mathrm{H}_{2} \mathrm{O} \longrightarrow \mathrm{HCO}_{3}{ }^{-}+\mathrm{H}_{3} \mathrm{O}^{+} \\
\mathrm{HCO}_{3}{ }^{-}+\mathrm{H}_{2} \mathrm{O} \longrightarrow \mathrm{CO}_{3}{ }^{2-}+\mathrm{H}_{3} \mathrm{O}^{+} \\
\mathrm{H}_{2} \mathrm{CO}_{3}+\mathrm{Ca}(\mathrm{OH})_{2} \longrightarrow \mathrm{CaCO}_{3}+2 \mathrm{H}_{2} \mathrm{O}
\end{gathered}
$$

According to reaction (5), $\mathrm{H}_{3} \mathrm{O}^{+}$is the main cause of reduction in the $\mathrm{pH}[12]$.

A few researchers have studied the effects of chloride ion attack on the diffusion and durability of concrete structures [13]. Kuzel's salt $\left(3 \mathrm{CaO} \cdot \mathrm{Al}_{2} \mathrm{O}_{3} \cdot 0.5 \mathrm{CaSO}_{4} \cdot 0.5 \mathrm{CaCl}_{2}\right.$. $\left.10(11) \mathrm{H}_{2} \mathrm{O}\right)$ and Friedel's salt $\left(3 \mathrm{CaO} \cdot \mathrm{Al}_{2} \mathrm{O}_{3} \cdot \mathrm{CaCl}_{2} \cdot 10 \mathrm{H}_{2} \mathrm{O}\right)$ can be formed where free chloride ions are available. The salts are considered hydrate calcium aluminate or AFm phases [14]. When chloride ions react with $\mathrm{HC}_{3}$, Friedel's salt is formed. The chloride ion reaction with $\mathrm{C}_{4} \mathrm{AF}$ leads to the formation of Kuzel's salt [15]. If Friedel's salt gets carbonated, some chloride ions bound by it may dissolute into the pore solution, and an increase in chloride ions may lead to a higher chloride ion ingress rate. Such ions reach the reinforcement bars, and according to the following reaction, this causes corrosion:

$$
\begin{gathered}
\mathrm{Fe}^{2+}+2 \mathrm{Cl}^{-} \longrightarrow \mathrm{FeCl}_{2} \\
\mathrm{FeCl}_{2}+2 \mathrm{H}_{2} \mathrm{O} \longrightarrow \mathrm{Fe}(\mathrm{OH})_{2}+2 \mathrm{HCl}
\end{gathered}
$$

Chloride-based deicing salts may harm infrastructures according to the following reactions [16] and a reduction in compressive strength and surface resistivity is caused by $\mathrm{CaCl}_{2}$ and $\mathrm{Mg}(\mathrm{OH})_{2}$ :

$$
\begin{aligned}
& \mathrm{Ca}(\mathrm{OH})_{2}+\mathrm{MgCl}_{2} \longrightarrow \mathrm{Mg}(\mathrm{OH})_{2}+\mathrm{CaCl}_{2} \\
& 3 \mathrm{Ca}(\mathrm{OH})_{2}+\mathrm{CaCl}_{2}+12 \mathrm{H}_{2} \mathrm{O} \\
& \longrightarrow 3 \mathrm{CaO}+\mathrm{CaCl}_{2}+15 \mathrm{H}_{2} \mathrm{O}
\end{aligned}
$$

Some researchers have studied the effect of carbonation and chloride penetration separately [17]. When exposed to $\mathrm{CO}_{2}$, chloride binding is reduced [18]. If $\mathrm{pH}$ drops below 12, a high amount of bounded chlorides are released. Therefore, such chlorides are known as a potential risk for corrosion [19]. Carbonation, however, leads to a reduction in chloride binding [20] which then increases the rate of chloride ion ingress [21]. Aside from the recent research performed by the authors of this paper [22], few studies have been performed on the effect of combined carbonation and chloride ion attack on concrete, although it has been stated that both of these factors affect the durability of concrete structures [23]. Yoon proved that the carbonation rate while concrete is exposed to carbonation and chloride ion ingress is much slower compared with the single carbonation condition.
When concrete is carbonated, free chloride content controls the total chloride content, because the concrete that is not carbonated has no binding capacity [23]. According to Yoon, when carbonation occurs, not only a decrease in $\mathrm{pH}$ but also a decrease in the binding capacity of chloride ions is highly possible. These changes will increase the risk of cracks due to corrosion. The effect of carbonation front progress in mortars containing fly ash in the presence of chloride ions has been studied recently [24]. In this paper, the effect of carbonation on the existence of chloride ions in specimens subjected to chloride ion ingress was investigated. Due to the refinement of the pores, it was found that specimens exposed to pure carbonation have more carbonation depth compared with the specimens subjected to chloride ion ingress and then carbonation.

In this study, the effect of simultaneous carbonation and chloride ion attack on mechanical characteristics and durability of concrete containing silica fume have been investigated through an accelerated test method. Specimens containing different amounts of silica fume $(0 \%, 7 \%$, and $10 \%)$ and water-to-binder ratios $(0.35,0.4$, and 0.45$)$ were maintained in an apparatus in which carbon dioxide $\left(\mathrm{CO}_{2}\right)$ pressure and concentration, ambient temperature, and relative humidity were kept constant, and wetting and drying cycles in saline water were applied automatically. The separate effects of carbonation and chloride ion attack were also investigated for the purpose of comparing the results. In order to evaluate the durability of silica fume concrete under simultaneous carbonation and chloride ion attack, measurements of water penetration, surface resistivity, sorptivity, $\mathrm{CO}_{2}$ consumption, carbonation, and chloride ion ingress depths were taken. In addition, phase change due to carbonation and chloride ion attack was monitored by $\mathrm{X}$-ray diffraction analysis (XRD), and microstructures and interfacial transition zones were studied by implementing a scanning electron microscope (SEM) as well as mercury intrusion porosimetry (MIP). As compressive strength, TEM analysis, and $\mathrm{CO}_{2}$ consumption, as well as SEM analysis, were thoroughly discussed in the previous paper [22], this paper will mostly consider the durability aspects; however, for a comprehensive discussion of durability properties, some data from the previous paper has been used.

\section{Materials and Methods}

2.1. Materials. Meeting ASTM C150 [25] specifications, the specimens were made with type I Portland cement, different amounts of silica fume, and potable water. The physical and chemical characteristics of cement and silica fume are presented in Table 1. Local natural river sand was used as fine aggregate and crushed stone as coarse aggregate, with maximum aggregate size of $4.75 \mathrm{~mm}$ and $19 \mathrm{~mm}$, respectively. The water absorption and specific gravity of fine and coarse aggregates were $2.5 \%$ and $1.6 \%$ and 2490 and $2550 \mathrm{~kg} / \mathrm{m}^{3}$, respectively. A liquid polycarboxylic-ether base with a solid content of $45 \%$ and a specific gravity of 1.2 was used as superplasticizer to provide suitable workability. 


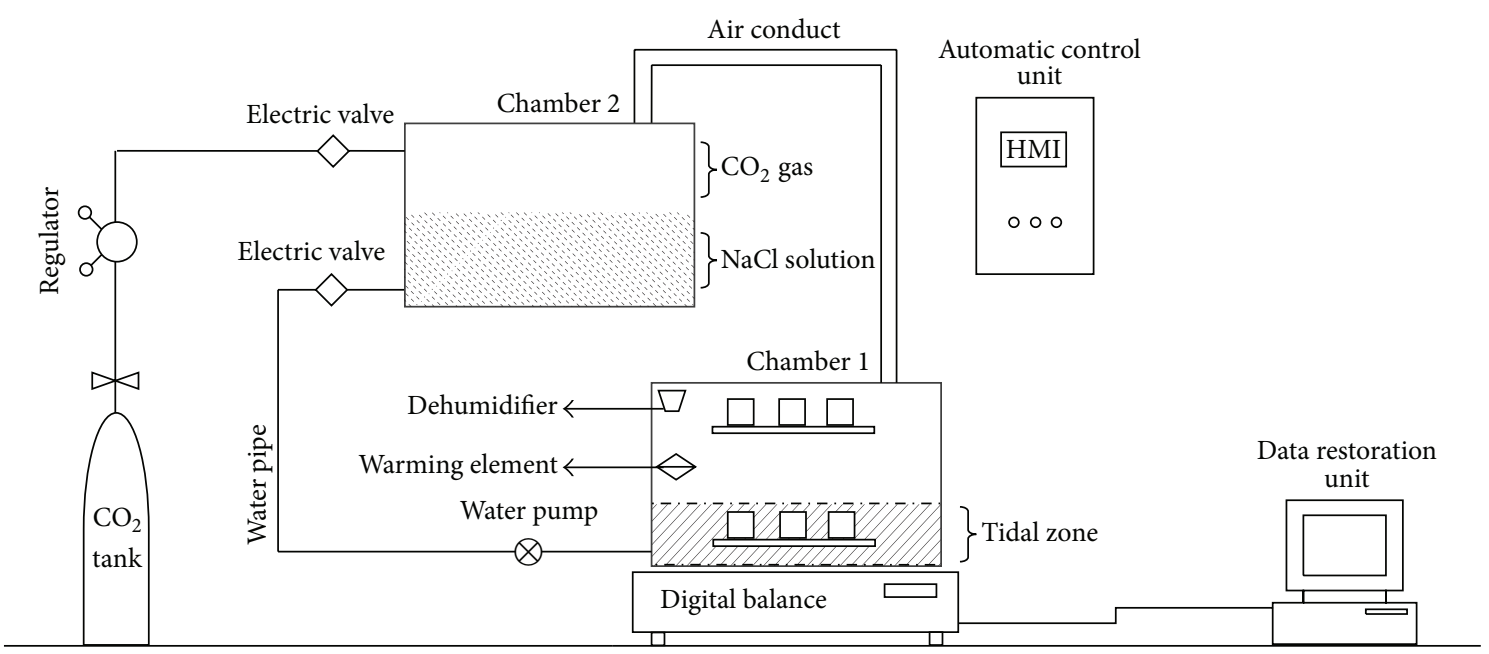

FIGURE 1: Apparatus for simultaneous carbonation and chloride ion attack.

TABLE 1: Characteristics of the cement and silica fume.

\begin{tabular}{lcc}
\hline $\begin{array}{l}\text { Oxide elements and chemical } \\
\text { composition }(\% \text { by mass })\end{array}$ & Cement $(\mathrm{C})$ & Silica fume $(\mathrm{S})$ \\
\hline Silicon dioxide $\left(\mathrm{SiO}_{2}\right)$ & 21.10 & 93.2 \\
Calcium oxide $(\mathrm{CaO})$ & 62.08 & 0.63 \\
Ferric oxide $\left(\mathrm{Fe}_{2} \mathrm{O}_{3}\right)$ & 2.74 & 0.24 \\
Aluminum oxide $\left(\mathrm{Al}_{2} \mathrm{O}_{3}\right)$ & 3.81 & 0.39 \\
Sulphate oxide $\left(\mathrm{SO}_{3}\right)$ & 2.6 & 0.23 \\
Magnesium oxide $(\mathrm{MgO})$ & 3.22 & 0.75 \\
Potassium oxide $\left(\mathrm{K}_{2} \mathrm{O}\right)$ & 0.73 & 0.21 \\
Sodium oxide $\left(\mathrm{Na}_{2} \mathrm{O}\right)$ & 0.12 & 0.23 \\
Phosphorus oxide $\left(\mathrm{P}_{2} \mathrm{O}_{5}\right)$ & 0.22 & - \\
Titanium oxide $\left(\mathrm{TiO}_{2}\right)$ & 0.24 & - \\
\hline $\mathrm{C}_{3} \mathrm{~S}$ & 51.1 & - \\
$\mathrm{C}_{2} \mathrm{~S}$ & 23.1 & - \\
$\mathrm{C}_{3} \mathrm{~A}$ & 5.1 & - \\
$\mathrm{C}_{4} \mathrm{AF}$ & 8.4 & - \\
\hline Loss on ignition $(\%)$ & 2.95 & 1.95 \\
Pozzolanic activity with cement $(\%)$ & - & $170-190$ \\
Physical properties & & 2.1 \\
$\quad$ Specific gravity & 3.17 & 6000 \\
Blaine fineness $\left(\mathrm{cm}^{2} / \mathrm{g}\right)$ & 3519 & 1.5 \\
Average diameter $(\mu \mathrm{m})$ & 15 & \\
\hline
\end{tabular}

2.2. Mixture Design and Specimens Preparation. For all mixtures, slump was kept constant at about $80 \mathrm{~mm}$ by adding adequate amounts of superplasticizer. All materials were batched in a 60 liter capacity vertical axis mixer with 3 different water/binder ratios: $0.35,0.4$, and 0.45 , and different percentages of silica fume replacement with cement at $0 \%$, $7 \%$, and $10 \%$ by weight. The mixture proportion is illustrated in Table 2. For both tests, mix design and curing condition, three specimens were tested. Specimens were vibrated and maintained at the temperature of $24 \pm 1^{\circ} \mathrm{C}$, for 24 hours and then demolded and cured in water at $24 \pm 2^{\circ} \mathrm{C}$. Since early carbonation can change the hydration procedure and calcium hydroxide content on the surface of concrete [5], specimens were cured for 7 days so that the test would have an impact on the normal procedure of hydration. After this period, $50 \%$ of the specimens were placed in the apparatus for simultaneous carbonation and chloride ion attack and also the pure carbonation condition. $25 \%$ of the specimens were cured in water for standard curing, and the rest were immersed in saline water. The apparatus is illustrated in Figure 1. Every 6 hours, saline water $(0.3 \%$ $\mathrm{NaOH}$ and $3 \% \mathrm{NaCl}[26]$ ) was pumped from chamber 1 (Ch.1) to chamber 2 (Ch.2) for the tide process simulation. By using a pneumatic valve, the interior pressure was kept constant at 1.5 bar [27] $\left(\mathrm{CO}_{2}\right.$ content of $\left.7500 \pm 100 \mathrm{ppm}\right)$ in order to accelerate the carbonation rate and to be sure that $\mathrm{CO}_{2}$ content is replenished while samples absorb the gas [28]. The temperature and relative humidity were controlled and kept constant at $23 \pm 2^{\circ} \mathrm{C}$ and $70 \pm 5 \%$, respectively. The specimens at the top of Ch.1 were not exposed to the saline water in order to provide the pure carbonation condition.

\section{Experimental Procedure}

\subsection{Physical Properties}

3.1.1. Phase Change Analysis. In order to quantify the phase changes, at the age of 28 days, $10 \mathrm{~mm}$ of the hydrated cement paste, with water-to-cement ratio of 0.35 , cured in all different conditions, was powdered, and X-ray diffraction (XRD) analysis was performed by a Philips powder diffractometer. The XRD sample preparation and instrument specifications are illustrated in Table 3. For phase quantification, a profile fit software (PANalytical X'Pert HighScore) was used.

3.1.2. Scanning Electron Microscope (SEM). At the age of 28 days, $5 \times 5 \times 2 \mathrm{~mm}$ pieces of 4 different types of specimens, including those cured in water, specimens that 
TABLE 2: Mixture proportion of specimens.

\begin{tabular}{|c|c|c|c|c|c|c|c|c|}
\hline \multirow{2}{*}{ Sample ID } & \multirow{2}{*}{ Water/binder } & \multirow{2}{*}{$\begin{array}{l}\text { Water } \\
\mathrm{kg} / \mathrm{m}^{3}\end{array}$} & \multicolumn{2}{|c|}{ Silica fume } & \multirow{2}{*}{$\begin{array}{c}\text { Cement content } \\
\mathrm{kg} / \mathrm{m}^{3}\end{array}$} & \multirow{2}{*}{$\begin{array}{c}\text { Coarse aggregate } \\
\mathrm{kg} / \mathrm{m}^{3}\end{array}$} & \multirow{2}{*}{$\begin{array}{l}\text { Fine aggregate } \\
\mathrm{kg} / \mathrm{m}^{3}\end{array}$} & \multirow{2}{*}{$\begin{array}{l}\text { Superplasticizer dosage } \\
\% \text { by paste volume }\end{array}$} \\
\hline & & & $\%$ & $\mathrm{~kg} / \mathrm{m}^{3}$ & & & & \\
\hline $35-0$ & \multirow{3}{*}{0.35} & \multirow{3}{*}{140} & 0 & 0 & 400 & \multirow{3}{*}{1018} & \multirow{3}{*}{833} & 1.6 \\
\hline $35-7$ & & & 7 & 28 & 372 & & & 1.75 \\
\hline $35-10$ & & & 10 & 40 & 360 & & & 2 \\
\hline $40-0$ & \multirow{3}{*}{0.4} & \multirow{3}{*}{160} & 0 & 0 & 400 & \multirow{3}{*}{990} & \multirow{3}{*}{810} & 1.3 \\
\hline $40-7$ & & & 7 & 28 & 372 & & & 1.45 \\
\hline $40-10$ & & & 10 & 40 & 360 & & & 1.7 \\
\hline $45-0$ & \multirow{3}{*}{0.45} & \multirow{3}{*}{180} & 0 & 0 & 400 & \multirow{3}{*}{963} & \multirow{3}{*}{788} & 1.2 \\
\hline $45-7$ & & & 7 & 28 & 372 & & & 1.4 \\
\hline $45-10$ & & & 10 & 40 & 360 & & & 1.5 \\
\hline
\end{tabular}

TABLE 3: XRD sample preparation and instrument specifications.

\begin{tabular}{lcccccc}
\hline Filler & Working condition & Range & Step size & Power & Sample preparation & Radiation \\
\hline Ni filler & $4^{\circ}-70^{\circ}$ & $2 \theta$ & $0.02^{\circ}$ & $40 \mathrm{kV}$ and $30 \mathrm{~mA}$ & Powder \\
\hline
\end{tabular}

were maintained in the apparatus with the water-to-cement ratio of 0.35 , and specimens with $10 \%$ silica fume, were coated with gold-palladium and scanned with Hitachi U8040 scanning electron microscope. Aggregates and cement paste were positioned at the center of the SEM separately for observation of carbonation and chloride ion ingress effects on microstructure and the interfacial transition zone.

3.1.3. Mercury Intrusion Porosimetry (MIP). Having been crushed by hammer, 2 grams of chunks from the specimens used for SEM analysis was randomly collected for mercury intrusion porosimetry (MIP) measurement. Three samples from each mix design and curing condition were tested at the age of 28 days. Chunks were kept in the oven at $60^{\circ} \mathrm{C}$ until they reached a constant weight. Pore Master33, with the ability to measure $6 \mathrm{~nm}$ to $950 \mu \mathrm{m}$, was used at the maximum pressure of 33000 psi. The intrusion and extrusion contact angle and surface tension of mercury were chosen to be $140^{\circ}$ and $0.480 \mathrm{~N} / \mathrm{m}$.

3.1.4. $\mathrm{CO}_{2}$ Permeance. As an indicator of permeability, the $\mathrm{CO}_{2}$ permeance is often measured, and in this research the test was performed to support the results obtained from the MIP experiment as well. For each condition, four specimens with a water-to-cement ratio of 0.35 were tested. The specimens in the dimension of $1 \times 1 \times 2.5 \mathrm{~cm}$ were placed into a tubular ceramic membrane and the holder was sealed. The experiment was performed as discussed by Xomeritakis et al. [29]. Having introduced gases one at a time into the tubular membrane, the permeation flow rate was obtained using a soap-film flowmeter. The gas pressure and stream were maintained at $15 \mathrm{psig}$ and $100 \mathrm{cc} / \mathrm{min}$, respectively. The gases used in this experiment are as follows, and their kinetic diameters are in parenthesis: $\mathrm{He}(2.6 \AA), \mathrm{CO}_{2}(3.3 \AA), \mathrm{Ar}$ (3.4 $\AA), \mathrm{N}_{2}$ (3.64 $\AA$ ), $\mathrm{CH}_{4}(3.8 \AA)$, and $\mathrm{SF}_{6}(5.5 \AA)$. Because $\mathrm{N}_{2}$ is inert and has the similar physical properties to air, it was implemented to simulate air in the experiment.
3.2. Durability Tests. All the durability tests were performed on the specimens cured in pure carbonation, pure chloride ion ingress, simultaneous carbonation, and chloride ion attack and the standard curing condition, shown as Carb, Chl, Sim, and PC in the figures, respectively. The following durability tests were performed on three samples for each of the curing conditions.

3.2.1. Surface Resistivity. The surface resistivity of $10 \times 20 \mathrm{~cm}$ cylinder specimens was measured at four quaternary longitudinal locations by the four-point Wenner array probe technique [30] at each test age, that is, 28 and 90 days. This nondestructive test shows the conductivity and ion penetration of the specimens.

3.2.2. Water Penetration. Regarding BS EN-12390-8:2000 [31], water penetration tests were performed to identify the permeability of concrete. For 72 hours, and under $0.5 \mathrm{MPa}$ pressure, $15 \times 15 \mathrm{~cm}$ cubic specimens were exposed to water on one face. After this period, specimens were split in order to measure maximum depth of penetration at the ages of 28 and 90 days.

3.2.3. Sorptivity. In order to identify the ability of moisture to penetrate into an unsaturated specimen, a sorptivity test was conducted on $10 \times 10 \mathrm{~cm}$ cubic specimens at the ages of 28 and 90 days. Specimens, according to BS EN-480-5 [32], were placed in an oven at the temperature of $60^{\circ} \mathrm{C}$ for 14 days. All specimens were $5 \mathrm{~mm}$ above the basin, and epoxy resin was sprayed on all surfaces except for the one which was exposed so that the water would was absorbed uniaxially. Mass changes were measured at $0,12,24,36$, and 72 hours. The sorptivity coefficient $(S)\left(\mathrm{m} / \mathrm{s}^{0.5}\right)$ was calculated according to (11)

$$
\frac{Q}{A}=C+S \sqrt{t},
$$




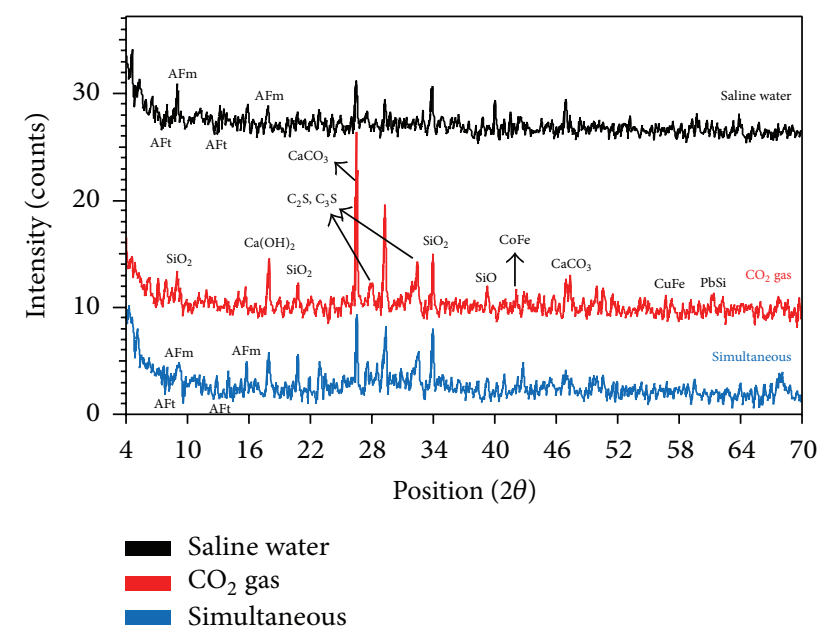

FIGURE 2: XRD analysis of 35-0 maintained in saline water, $\mathrm{CO}_{2}$ gas, and simultaneous $\mathrm{CO}_{2}$ gas and saline water at 28 days, from top to bottom.

where $Q$ is obtained from the amount of water that is absorbed; $A$ is the surface area of the sample in contact with water in square meter; $t$ is the time of the test in seconds; $C$ is the constant coefficient.

3.2.4. Carbonation and Chloride Ion Ingress Depths. $10 \times$ $20 \mathrm{~cm}$ cylinder specimens at the ages of 28 and 90 days were sliced to $5 \mathrm{~mm}$ thickness for $\mathrm{pH}$ measurement in order to identify carbonation depth by spraying a $\mathrm{pH}$ indicator solution ( $0.1 \mathrm{~g}$ phenolphthalein in $100 \mathrm{~mL} 95 \%$ ethanol). Meanwhile, another slice $5 \mathrm{~mm}$ thick was used for measuring the depth of chloride ion penetration. The measuring was performed by spraying a silver nitrate $\left(\mathrm{AgNO}_{3}\right)$ solution and is suitable for indicating chloride ion ingress.

\section{Results and Discussion}

4.1. Phase Change Analysis. The effect of different conditions on phase change can be observed by means of Xray diffractometer (XRD). The results of XRD at the age of 28 days for samples with a water-to-cement ratio of 0.35 , maintained at different curing conditions, are shown in Figure 2. The samples are chosen randomly from a $5 \mathrm{~mm}$ of the depth surface in order to consider carbonation and chloride ion ingress effect. Portlandite $\left(\mathrm{Ca}(\mathrm{OH})_{2}\right)$, calcite $\left(\mathrm{CaCO}_{3}\right)$, and silicon dioxide $\left(\mathrm{SiO}_{2}\right)$, as crystalline phases, are the main peaks $[33,34]$. The oxide elements and chemical compositions presented in Table 1 support the accuracy of the test.

As stated above, Kuzel's salt $\left(3 \mathrm{CaO} \cdot \mathrm{Al}_{2} \mathrm{O}_{3} \cdot 0.5 \mathrm{CaSO}_{4}\right.$. $\left.0.5 \mathrm{CaCl}_{2} \cdot 10(11) \mathrm{H}_{2} \mathrm{O}\right)$ and Friedel's salt $\left(3 \mathrm{CaO} \cdot \mathrm{Al}_{2} \mathrm{O}_{3} \cdot \mathrm{CaCl}_{2}\right.$. $10 \mathrm{H}_{2} \mathrm{O}$ ) can be formed where free chloride ions are available. The salts are considered as hydrate calcium aluminate or AFm phases [14]. When chloride ions react with $\mathrm{C}_{3} \mathrm{H}$, Friedel's salt is formed. The chloride ion reaction with $\mathrm{C}_{4} \mathrm{AF}$ leads to the formation of Kuzel's salt [15]. If Friedel's salt gets carbonated, some chloride ions bound by Friedel's salt may dissolute into pore solution, and an increase in chloride ions may lead to a higher chloride ion ingress rate. Sulfate is mostly found in AFt, which contains ettringite and thaumasite, and causes reactions which extenuate the sulfate concentration in the pores. In addition, sulfate and carbonate react with each other in a strong way [35]. Ettringite is formed in a crystalline hexagonal needle shape with the size of $4-10 \mu \mathrm{m}$ early in the cement hydration process. When in contact with water, it remains stable until the temperature rises above $114^{\circ} \mathrm{C}$ [36], and when the humidity decreases, the temperature decreases rapidly as well [37]. Thaumasite, on the other hand, is formed when alumina is changed to silicate in ettringite. It is stable at the temperature of about $30^{\circ} \mathrm{C}$. Due to the low carbonate content and also low silica activity, thaumasite is rarely formed unless carbonate is applied externally or internally from calcium carbonate. AFm phases generally contain a layer which is elementary, for example, $\mathrm{Ca}_{2}\left[\mathrm{Al}(\mathrm{OH})_{6}\right]^{+}$. Sulfate AFm has been reported to be stable at temperatures lower than $50^{\circ} \mathrm{C}$ [38]. AFm phases are made up of sheets of $\mathrm{M}(\mathrm{OH})_{6}$ octahedral ions and are considered as a branch of hydrated calcium aluminate phases. It is noteworthy that AFm anions in Portland cement are carbonate, hydroxide, and sulfate; however, they are considered aluminosilicate particles in a blended cement [14] in which other anions are replaced with chloride. It should be noted that the AFm phase pattern obtained from XRD is similar to $\mathrm{C}_{4} \mathrm{AH}_{13}$ which is a type of AFm phase with hydroxide [14]. Moreover, AFt particles that have a needle shape can be seen in the SEM micrographs with a size of up to $4 \mu \mathrm{m}$. When carbonate replaces all the sulfate in AFm, ettringite reaches its maximum concentration [14].

According to the results, $\mathrm{Ca}(\mathrm{OH})_{2}$ has been reduced and consequently $\mathrm{CaCO}_{3}$ has been increased in the $\mathrm{CO}_{2}$ environment which is shown in Figure 9; however, specimens maintained in the tidal zone have lesser amounts of $\mathrm{CaCO}_{3}$, perhaps due to the preventative effect of moisture available at the surface. Further, saline water can wash $\mathrm{CO}_{2}$ that may penetrate into the concrete. The reduction in $\mathrm{Ca}(\mathrm{OH})_{2}$ signifies that carbonation consumes $\mathrm{Ca}(\mathrm{OH})_{2}$ and produces $\mathrm{CaCO}_{3}$. Moreover, $\mathrm{C}_{2} \mathrm{~S}$ and $\mathrm{C}_{3} \mathrm{~S}$ have also been reduced; hence, the production of $\mathrm{CaCO}_{3}$ is not only due to $\mathrm{Ca}(\mathrm{OH})_{2}$. XRD results validate the fact that carbonation has occurred mostly in the proximity of the surface since the peaks of $\mathrm{Ca}(\mathrm{OH})_{2}$ are weak at points far from the surface. Furthermore, by using silica fume, more $\mathrm{CH}$ may be converted to C-S-H gel. Evidence for this reaction is shown in Figure 2. Specimens maintained in $\mathrm{CO}_{2}$ gas had a lower peak for $\mathrm{Ca}(\mathrm{OH})_{2}$ and a higher peak for $\mathrm{C}_{2} \mathrm{~S}, \mathrm{C}_{3} \mathrm{~S}$, and $\mathrm{CaCO}_{3}$. In the range of $2 \theta$ between $18^{\circ}$ and $42^{\circ}$, because of the nonconvex shape of the $\mathrm{XRD}$ results, crystalline materials of carbonation products may have been available.

4.2. Surface Resistivity. Relative permeability of specimens can be evaluated by this nondestructive test. If a specimen has a higher surface resistivity (SR), it signifies more durability. Regarding the results of SR values presented in Figures 3 and 4, silica fume has improved the surface resistivity. Silica fume improves surface resistivity by two reactions: (i) it produces $\mathrm{C}-\mathrm{S}-\mathrm{H}$ gel by its reaction with $\mathrm{CH}$, which fills the interfacial transition zone; although silica fume 
has little or no cementitious feature, it chemically reacts with calcium hydroxide and forms compounds which have cementitious properties [39]; (ii) silica fume particles with an average diameter of $150 \mathrm{~nm}$ are significantly finer than cement particles with average diameter of $15 \mu \mathrm{m}$; therefore, they can fill pores which may improve surface resistivity [40]. In other words, silica fume would alter the concrete strength because of its fineness or C-S-H gel production [41] and the existence of small particles will improve the concrete properties known as "particle packing" or "microfilling."

It was expected to have a synergic effect in the tidal zone where simultaneous carbonation and chloride ion attack happen. However, the observed reduced surface resistivity, compared to specimens maintained in $\mathrm{CO}_{2}$ gas, could be due to the moisture that is available near the surface, hindering $\mathrm{CO}_{2}$ from penetrating into the pores of the specimens. In fact, saline water has washed the surface, so the process of forming carbonation products has been delayed. During carbonation, $\mathrm{CO}_{2}$ reacts with cementitious materials, an important product of which is calcium carbonate $\left(\mathrm{CaCO}_{3}\right)$, which is stronger than $\mathrm{Ca}(\mathrm{OH})_{2}$; therefore, the specimen would become stronger at the surface [11]. One positive effect of using silica fume is providing more C-S-H gel [42], causing the ultimate hydration products to become stronger, and more surface resistivity is obtained. As silica fume fills the pores, meanwhile, less porosity is obtained by lower water/binder ratio as well. Moreover, the moisture at the surface provided less room for the carbonation products to get formed. More C-S-H gel is provided by silica fume, which makes the ultimate hydration products become stronger. The moisture that is available near the surface of the specimen hinders $\mathrm{CO}_{2}$ penetration. In other words, the formation of carbonation products has been delayed because saline water has washed the surface. In the same way, carbonated specimens have a higher SR value; however, specimens maintained in the tidal zone did not have a high value of surface resistivity which could be due to the moisture available at the surface of specimens during the simulation of four tide cycles of six hours per day. Carbonation products can fill the pores according to the following equation:

$$
\mathrm{H}_{2} \mathrm{CO}_{3}+\mathrm{Ca}(\mathrm{OH})_{2} \longrightarrow \mathrm{CaCO}_{3}+2 \mathrm{H}_{2} \mathrm{O}
$$

Also with $\mathrm{CaCO}_{3}$ more strength can be obtained from the carbonated area. According to the results, there is a slight difference in SR values between the control and specimens maintained in saline water, because saline water cannot change any phase in the hydration products. According to Figures 3 and 4, 35-10 samples maintained in $\mathrm{CO}_{2}$ have the highest surface resistivity, which is about 60 and $80 \%$ higher than that of 35-0 samples at the ages of 28 and 90 days, respectively.

4.3. Water Penetration. Another way of measuring the permeability of specimens is to perform a water penetration test. Since durability is related to the permeability of concrete, a low depth of water penetration is tantamount to a low rate of chloride ion penetration and consequently higher durability. The results of water penetration tests for all specimens with

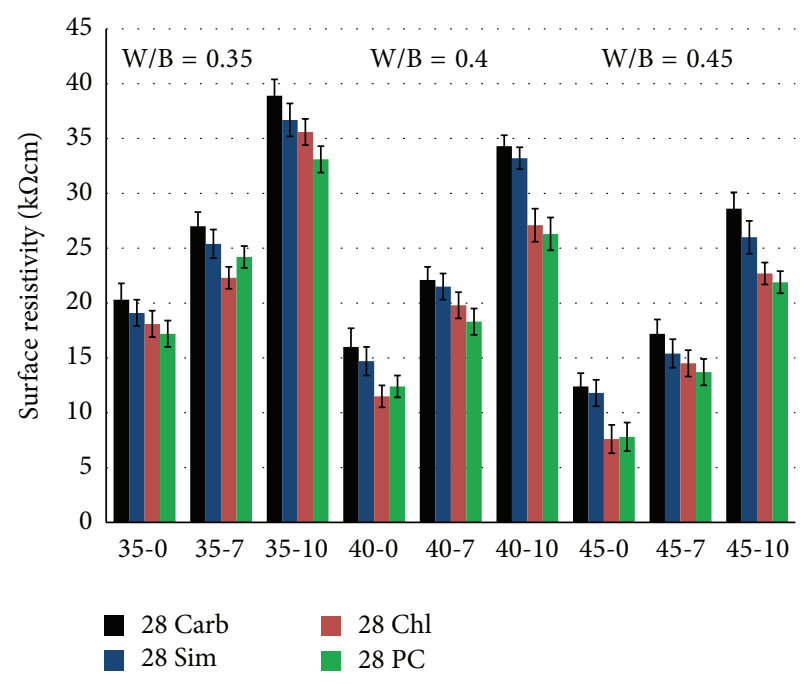

FIGURE 3: Results of surface resistivity at the age of 28 days.

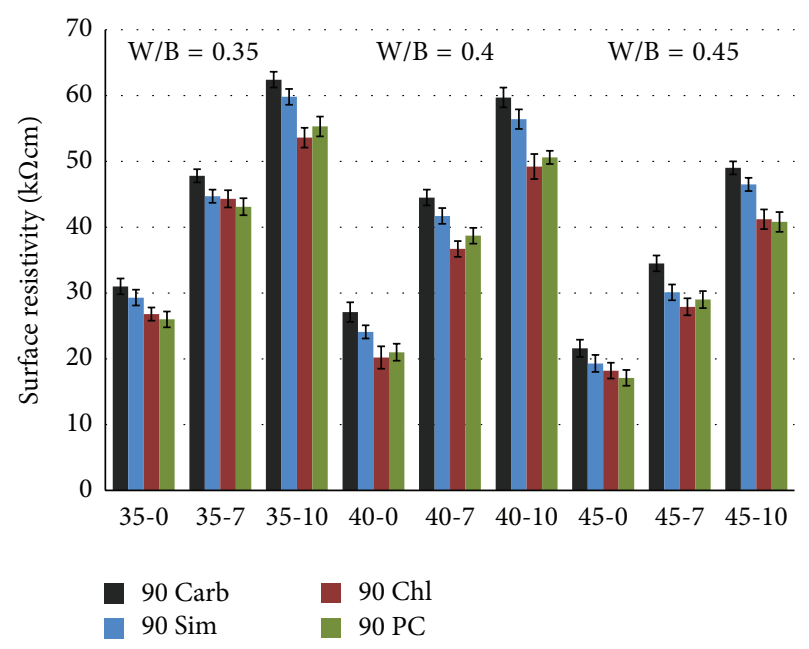

FIGURE 4: Results of surface resistivity at the age of 90 days.

different curing conditions and amounts of silica fume at the ages of 28 and 90 days are shown in Figures 5 and 6 , respectively. According to the results, using silica fume reduced water penetration depth. The minimum depth of water penetration was $16 \mathrm{~mm}$ for the specimen with $10 \%$ silica fume and water/binder ratio of 0.35 at the age of 90 days. The reduction in water penetration depth is attributed to the double action of silica fume, that is, acting as filler and producing $\mathrm{C}-\mathrm{S}-\mathrm{H}$ gel; silica fume particles with an average diameter of $150 \mathrm{~nm}$ are significantly finer than cement particles with an average diameter of $15 \mu \mathrm{m}$; therefore, they can fill pores which may improve surface resistivity [40]. On the other hand, a low water/binder ratio, which causes less porosity, is another element that has caused this imperceptible depth of water penetration. Moreover, specimens maintained in $\mathrm{CO}_{2}$ gas showed a significant reduction in the depth of water penetration due to the carbonation products such as $\mathrm{CaCO}_{3}$ that could fill the pores. Reduction in the pores can be explained through reactions (1) and (2) [7]. By consumption 


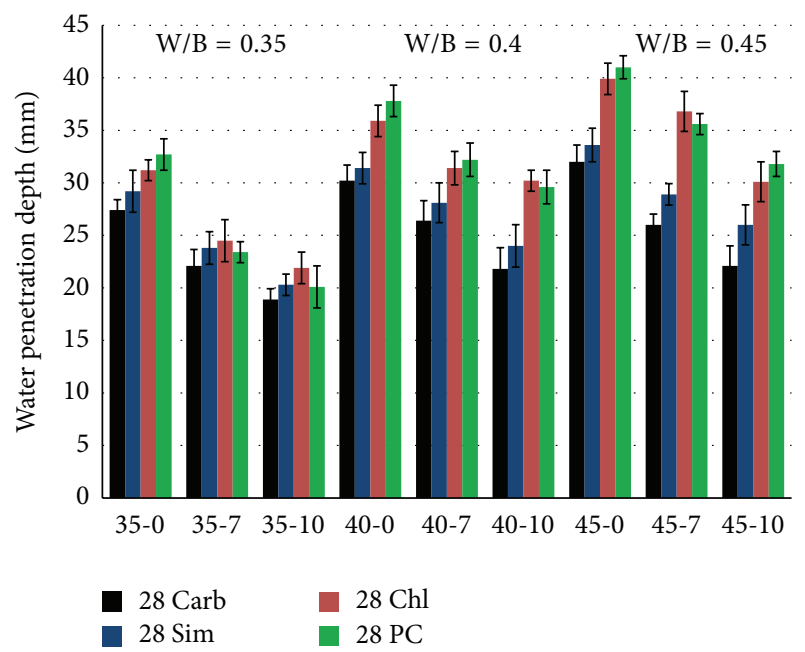

FIGURE 5: Water penetration depth for all specimens in different conditions at the age of 28 days.

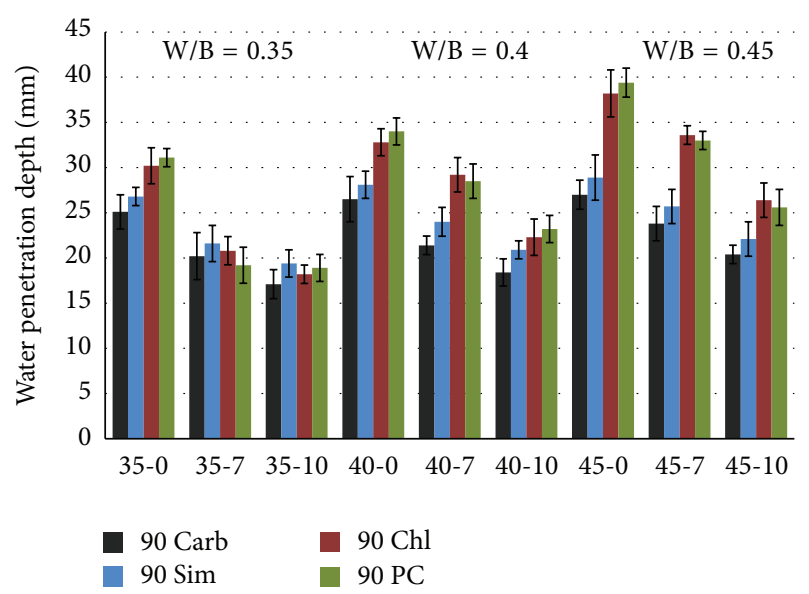

FIgURE 6: Water penetration depth for all specimens in different conditions at the age of 90 days.

of $(\mathrm{OH})^{-}$in reaction (1), the $\mathrm{pH}$ of the pore solution decreases which leads to a decrease in overall porosity $[7,9]$.

There was no significant difference between the water penetration depths for the reference concrete and specimens maintained in saline water, which is due to the availability of moisture present at the surface of specimens maintained in $\mathrm{CO}_{2}$ gas and saline water, hindering the penetration of gas and chloride into the specimens. The minimum depth of water penetration was $16 \mathrm{~mm}$ for the sample 35-10 maintained in $\mathrm{CO}_{2}$ approximately $10 \%$ lower than that of the reference and the saline water-maintained specimen at the age of 28 days. The results support the validity of the premise that saline water can not cause any reaction in cement hydration products; hence, there is no perceptible change in porosity. Specimens in the tidal zone were observed to have a depth of water penetration more than that of specimens maintained in $\mathrm{CO}_{2}$ gas.

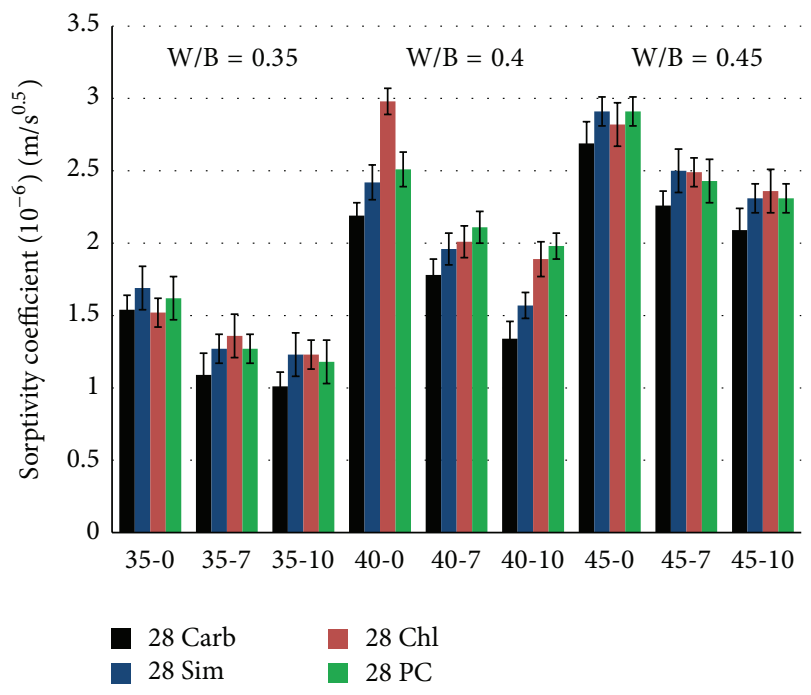

FIGURE 7: Sorptivity coefficient for all specimens maintained in different conditions at the age of 28 days.

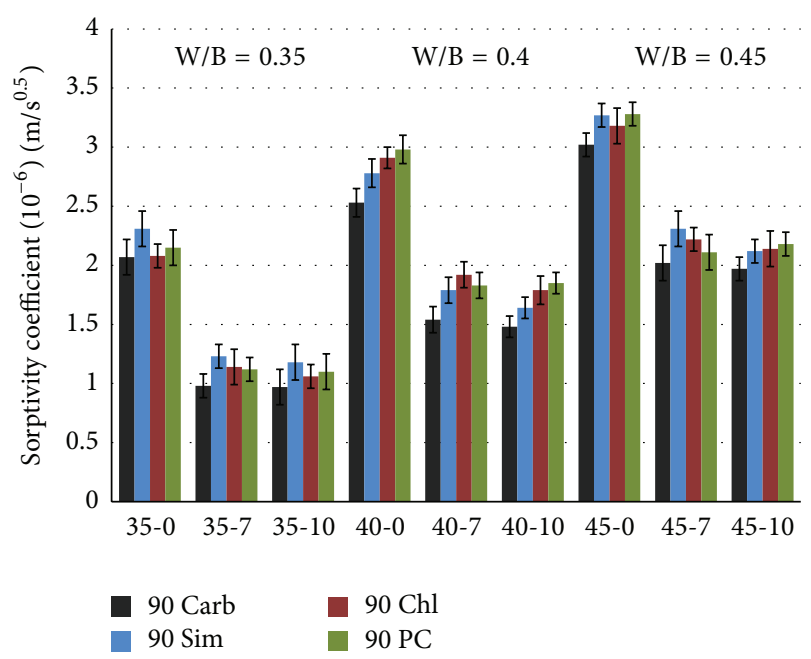

FIGURE 8: Sorptivity coefficient for all specimens maintained in different conditions at the age of 90 days.

4.4. Sorptivity. Sorptivity coefficient $(S)$ is an index of durability, and a higher sorptivity coefficient connotes more capillary porosity; however, not all capillary porosities are responsible for the durability of concrete. Capillary porosities that are connected with each other can affect durability [43]. The results of sorptivity coefficient $(S)$ at the ages of 28 and 90 days are shown in Figures 7 and 8, respectively, which support the results obtained in the previous section from the water penetration test. As stated previously, by the consumption of $(\mathrm{OH})^{-}$in $\mathrm{Ca}(\mathrm{OH})_{2}+\mathrm{CO}_{2} \rightarrow \mathrm{CaCO}_{3}+\mathrm{H}_{2} \mathrm{O}$, the $\mathrm{pH}$ of the pore solution increases; meanwhile, a decrease in overall porosity is happening through the production of $\mathrm{CaCO}_{3}$ in $\mathrm{C}-\mathrm{S}-\mathrm{H}+2 \mathrm{CO}_{2} \rightarrow \mathrm{SiO}_{2}+2 \mathrm{CaCO}_{3}+\mathrm{H}_{2} \mathrm{O}[7,9]$. When compared to specimens maintained in saline water or the standard curing condition, specimens maintained in $\mathrm{CO}_{2}$ gas and the tidal zone have lower sorptivity coefficients. This 


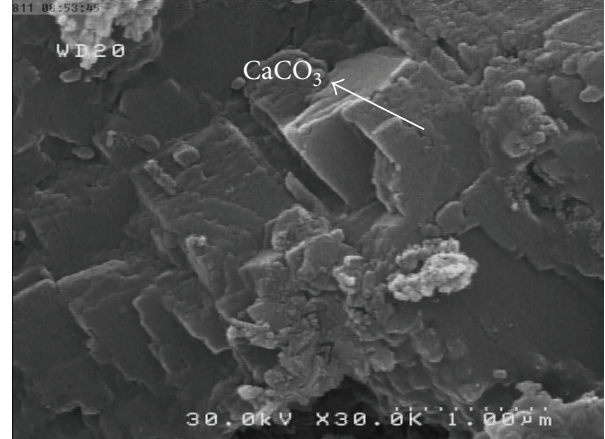

FIGURE 9: 35-0 maintained in $\mathrm{CO}_{2}$ gas.

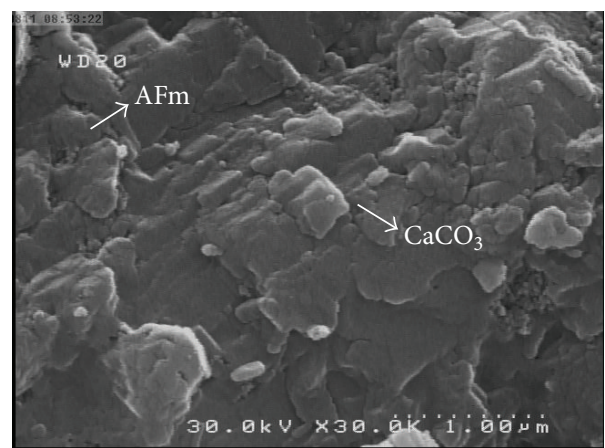

Figure 10: 35-0 maintained in tidal zone.

is probably due to the filling effect of carbonation products that can block capillary porosities, although $\mathrm{CaCO}_{3}$ may fill some of those porosities as well. However, because of the moisture available in the proximity of the surface, which prohibits $\mathrm{CO}_{2}$ gas from entering into the specimens, the sorptivity coefficients for the specimens maintained at the tidal zone are higher than those of the $\mathrm{CO}_{2}$ maintained specimens. Furthermore, using silica fume has tangibly reduced the sorptivity coefficient. At the age of 90 days, the 35-10 sample maintained in $\mathrm{CO}_{2}$ gas has the minimum sorptivity coefficient of about $10^{-6}\left(\mathrm{~m} / \mathrm{s}^{0.5}\right)$ while the $45-0$ sample has the maximum value of $3.3\left(10^{-6}\right)\left(\mathrm{m} / \mathrm{s}^{0.5}\right)$ when maintained in the standard curing condition. The results indicate that silica fume has reduced capillary porosity. Meanwhile, because of the finer size of silica fume than cement particles, some pores may have been filled, and the inner conductivity of pores may have been blocked. Silica fume improves surface resistivity by two reactions: it produces $\mathrm{C}-\mathrm{S}-\mathrm{H}$ gel by its reaction with $\mathrm{CH}$, which fills interfacial transition zones; silica fume chemically reacts with calcium hydroxide and forms compounds which have cementitious properties [39], even though it has few cementitious features.

4.5. SEM and MIP Results. Small gold coated portions of specimens were placed in the scanning electron microscope (SEM) stubs. The micrographs of the polished surface of the 35-0 sample for hydrated concrete specimens, maintained in different conditions, at the age of 28 days, are illustrated in Figures 9-13. The samples are chosen randomly from

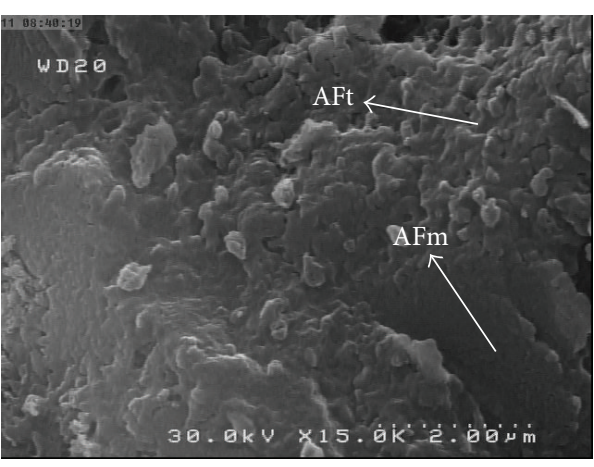

FIGURE 11: 35-0 maintained in saline water.

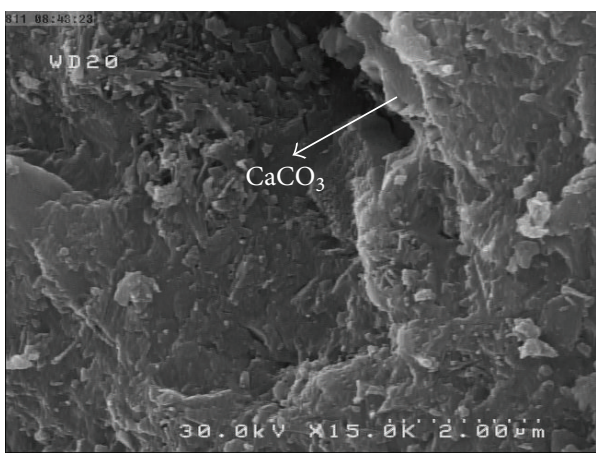

FIGURE 12: 35-0 maintained in standard curing condition.

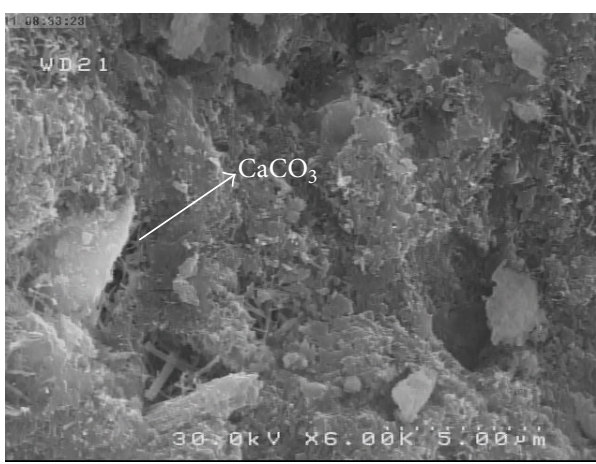

FIGURE 13: 35-10 maintained in tidal zone.

the $5 \mathrm{~mm}$ of the surface in order to consider carbonation and chloride ion ingress effect. In the micrographs, C-S-H gel appears slightly brighter, and aggregates appear darker. Sands can be described by their semidark hue [44]. The 35-0 specimen micrographs maintained in $\mathrm{CO}_{2}$ gas, in the tidal zone, saline water, and standard curing conditions, are presented in Figures 9-12, respectively. According to the SEM micrographs, 35-0 maintained in $\mathrm{CO}_{2}$ gas has many cubic, crystalline particles that have been formed because of carbonation. As mentioned above, by polymerizing silicate chains in C-S-H, volume decreases and shrinkage happens as well [3]. Besides, $\mathrm{CaCO}_{3}$ is available in various forms which may increase surface resistivity. When compared to the saline water-cured sample, the sample in the tidal zone, developed 
TABLE 4: Mercury intrusion porosimetry results.

\begin{tabular}{lccc}
\hline Label & Total intruding volume $(\mathrm{mL} / \mathrm{g})$ & Mean radius $(\mathrm{nm})$ & Total porosity $(\%)$ \\
\hline 35-0 Carb & $0.1191 \pm 7.1 \%$ & $15.26 \pm 8.6 \%$ & 10.2 \\
$35-0$ Sim & $0.1250 \pm 5.3 \%$ & $20.55 \pm 7.2 \%$ & 13.5 \\
$35-0$ Chl & $0.1507 \pm 8.7 \%$ & $23.92 \pm 5.7 \%$ & 15.7 \\
$35-0$ PC & $0.1459 \pm 6.8 \%$ & $20.71 \pm 6.6 \%$ & 16.2 \\
$35-10$ Sim & $0.0832 \pm 6.5 \%$ & $11.51 \pm 5.1 \%$ & 8.9 \\
\hline
\end{tabular}

cubic, crystalline particles, and $\mathrm{CaCO}_{3}$ was reduced. As a comprehensive porosity analysis will be published in another paper, the specimens used in the SEM analysis were tested using MIP in order to obtain total porosity values. A preliminary analysis of the porosity of the specimens shows that the 35-10 sample cured in the tidal zone has $50.1 \%$ less total porosity than the sample 35-0 cured in the same condition. The results are presented in Table 4 . It is also visible that carbonated specimens have less porosity than specimens maintained in the tidal zone.

Furthermore, in both conditions, capillary porosity has been reduced leading to a lower sorptivity coefficient. The carbonated $35-0$ sample has $32.4 \%$ less total porosity than the 35-0 sample cured in the tidal zone. Total porosity signifies the porosity that is responsible for capillary transportation through the concrete porous structure [45]. In Figure 9, in the 35-0 sample (Figure 10) maintained in saline water, no perceptible difference can be observed when compared to the 35-0 sample cured in the standard curing condition. It can be concluded that, by curing in saline water, no chemical or physical reaction has taken place. According to the result of gas permeation, the minimum pore size can be estimated at less than $50 \AA$ because the ratio of $\mathrm{He}_{\mathrm{SF}} \mathrm{SF}_{6}$ is approximately 1000. Carbonation has led to a less permeable surface and the specimens maintained in both carbonation and chloride ion ingress show less permeability compared with plain concrete and the specimens maintained in the pure chloride ion ingress. The results support the values obtained from the durability test and MIP tests. A more detailed discussion and comprehensive porosity analysis will be presented in the forthcoming manuscript by the authors.

The 35-10 specimen micrographs (at 6kx magnification), maintained in the tidal zone, are presented in Figure 13. Regarding these SEM micrographs, silica fume has filled some pores, and the microstructure of the transition zone has been improved because of the production of C-S-H gel. Carbonation and silica fume have had a synergistic effect. When compared to carbonated samples without silica fume, reduced water penetration depth and sorptivity were observable, and increased surface resistivity and less porosity were noticed. According to Figure 13 and Table 4, it is evident that silica fume has filled pores although minimally, and using $10 \%$ silica fume may compensate for the effect of carbonation because of the capillary porosity blocking effect. Silica fume would alter the concrete's strength because of its fineness or C-S-H gel production [41] and the existence of small particles will improve the concrete properties known as "particle packing" or "microfilling."

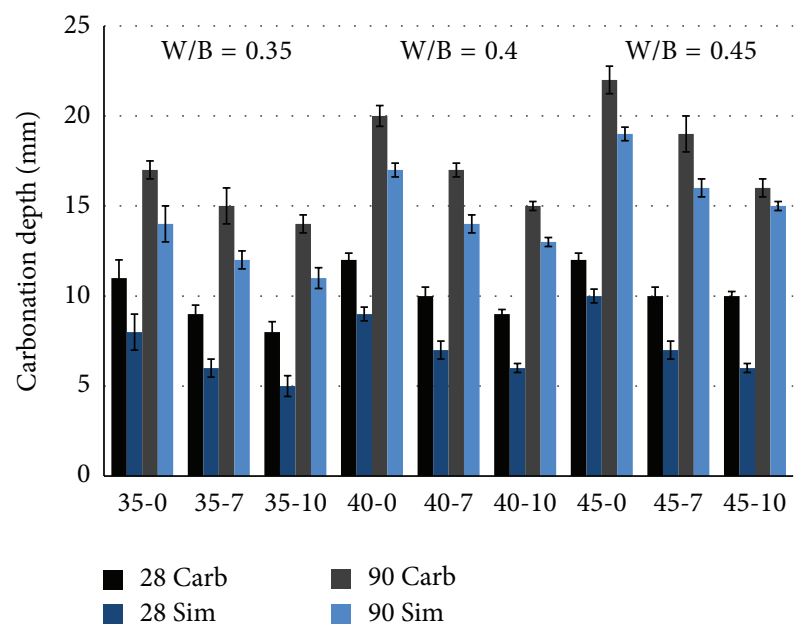

FIGURE 14: Results of the depth of carbonation.

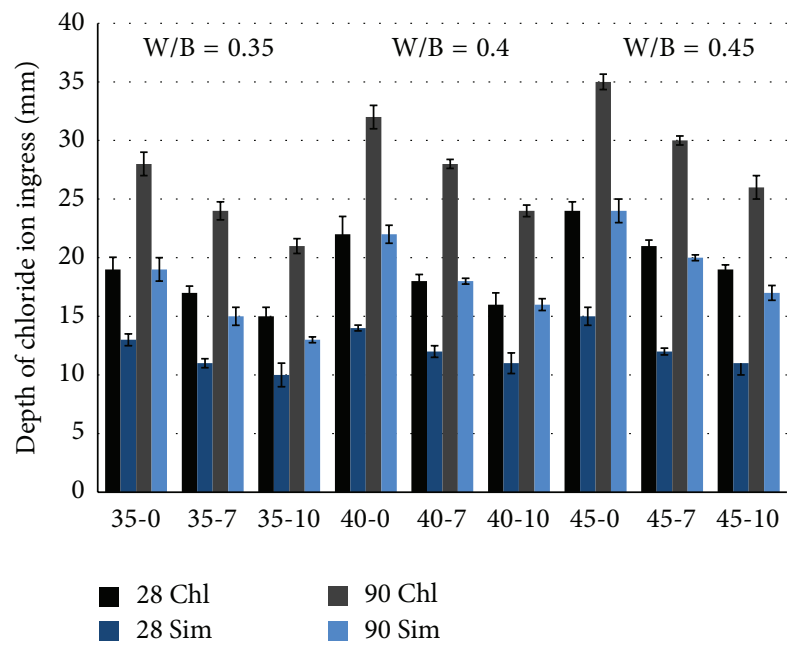

FIGURE 15: Results of the depth of chloride ion ingress.

4.6. Depth of Carbonation and Chloride Ion Ingress. In order to indicate carbonation depth and the depth of chloride ion ingress, phenolphthalein and silver nitrate solutions were sprayed separately on the surface of $5 \mathrm{~mm}$ thick slices. The results of the depth of carbonation and chloride ion ingress for specimens maintained in each environment condition, at the ages of 28 and 90 days, are presented in Figures 14 and 15 , respectively. The minimum depth of carbonation and chloride ion ingress for specimens maintained at the tidal 
zone was 5 and $10 \mathrm{~mm}$ for $35-10$, while the maximum was 23 and $35 \mathrm{~mm}$ for $45-0$, respectively. The results support the conclusion that silica fume fills pores so that there is less space for $\mathrm{CO}_{2}$ gas and carbonation products. Besides that, because of less capillary porosity due to the presence of silica fume and its productions, that is, C-S-H gels, less chloride ions could penetrate into the specimen. Reduction in $\mathrm{pH}$, which was about 12 to 9 in this experiment, was partly due to the production of $\mathrm{CaCO}_{3}$ from $\mathrm{Ca}(\mathrm{OH})_{2}$. This reaction occurred in a $15 \mathrm{~mm}$ range at the surface, and therefore, signs of corrosion for reinforcement bars, located $50 \mathrm{~mm}$ from the surface, may not occur. By using $10 \%$ silica fume and a water/binder ratio of 0.35 , at the tidal zone, corrosion of reinforcement bars is not likely to happen in 90 days; however, the depth of carbonation for specimens maintained in $\mathrm{CO}_{2}$ gas, which is about $50 \mathrm{~mm}$ from the surface, is detrimental to reinforcement bars. In fact, the $\mathrm{pH}$ presolution is not related merely to $\mathrm{Ca}(\mathrm{OH})_{2}$; rather, alkali salts such as $\mathrm{NaOH}$ and $\mathrm{KOH}$ are important since they are more likely to be carbonated. Moreover, carbonation depth for specimens maintained in $\mathrm{CO}_{2}$ gas was at least $45 \%$ higher than that of specimens maintained at the tidal zone. The minimum carbonation depth was $5 \mathrm{~mm}$ for $35-10$ samples, which is $140 \%$ lower than that of 45-0 samples. Furthermore, chloride ion ingress for specimens maintained in saline water followed the same procedure explained above. The minimum and maximum depths of chloride ion ingress were 10 and $35 \mathrm{~mm}$ for $35-10$ and $45-0$, respectively.

\section{Extension of This Work}

As it is almost always the case, unsolved problems remain. One of the most important follow-up experiments is the exact chemical reactions that take place in each step, from the first day of casting to 90 days of curing. Therefore, an extensive research on the petrography of the specimens and porosity measurements as well as extracting the penetration profile of chloride ion seems useful for further discussion. Besides, a multiscale dynamic simulation is necessary to find out the precise effect of curing in different curing conditions. This work has been commenced and will also be reported in due course.

\section{Conclusions}

In this study, extensive experimentation was carried out to determine the effect of an accelerated test method of simultaneous carbonation and chloride ion attack on mechanical properties and the durability of concrete containing silica fume. The primary findings are as follows:

(1) Results of XRD tests revealed that carbonation consumed $\mathrm{Ca}(\mathrm{OH})_{2}$, produced $\mathrm{CaCO}_{3}$, and reduced $\mathrm{C}_{2} \mathrm{~S}$ and $\mathrm{C}_{3} \mathrm{~S}$ especially near the surfaces of the samples.

(2) Silica fume has filled pores, and the microstructure of the transition zone has been improved because of the production of C-S-H gel, which may lead to an increase in surface resistivity and a reduction in water penetration depth and sorptivity.
(3) Compared with the specimens maintained in $\mathrm{CO}_{2}$, specimens maintained at the tidal zone could not reach that value of surface resistivity, which could be due to the moisture available at the surface of specimens during the simulation of four tidal cycles of six hours per day.

(4) The minimum depth of water penetration was $16 \mathrm{~mm}$ for sample 35-10 maintained in $\mathrm{CO}_{2}$ which was about $10 \%$ lower than that of the reference and the saline water-maintained specimen at the age of 28 days.

(5) A preliminary analysis of the porosity of the specimens shows that the 35-10 sample cured in the tidal zone has $50.1 \%$ less total porosity than the sample 35 0 cured in the same condition. Furthermore, in both conditions, capillary porosity has been reduced leading to a lower sorptivity coefficient. The carbonated $35-0$ sample has $32.4 \%$ less total porosity than the $35-$ 0 sample cured in the tidal zone.

(6) Silica fume physically and chemically fills the pores of specimens and reduces carbonation depth. Similar results were obtained for chloride ion penetration.

(7) The maximum and minimum $\mathrm{CO}_{2}$ consumption for specimens maintained in $\mathrm{CO}_{2}$ gas was $14.6 \%$ and $10.6 \%$ for $45-0$ and $35-10$ samples, respectively, and the $\mathrm{CO}_{2}$ consumption for specimens maintained at the tidal zone was at least approximately $15 \%$ lower than that of specimens maintained in $\mathrm{CO}_{2}$ gas.

(8) The minimum depth of carbonation and chloride ion ingress for specimens maintained at the tidal zone is 5 and $10 \mathrm{~mm}$ for 35-10 when simultaneously maintained in $\mathrm{CO}_{2}$ gas and saline water.

(9) Reduction in $\mathrm{pH}$, which is about 12 to 9 in this experiment, is partly due to the production of $\mathrm{CaCO}_{3}$ from $\mathrm{Ca}(\mathrm{OH})_{2}$, and this reaction is mostly occurring in $15 \mathrm{~mm}$ from the surface.

\section{Competing Interests}

The authors declare that they have no competing interests.

\section{Acknowledgments}

This study was funded by the Concrete Technology \& Durability Research Center. The authors thank Eng. Alireza Ghahari for his support. Special thanks go to Mohammad Mehdi Haji Ghahremanzade from the XRD center for his help with the XRD analyses and Atousa Khazaei from the Microscopy Center for her support with the FESEM and MIP analyses.

\section{References}

[1] P. K. Mehta and P. J. Monteiro, Concrete: Microstructure, Properties, and Materials, vol. 3, McGraw-Hill, New York, NY, USA, 2006.

[2] X.-M. Wan, F. H. Wittmann, T.-J. Zhao, and H. Fan, "Chloride content and $\mathrm{pH}$ value in the pore solution of concrete under 
carbonation," Journal of Zhejiang University: Science A, vol. 14, no. 1, pp. 71-78, 2013.

[3] T. Bier, J. Kropp, and H. Hilsdorf, "Formation of silica gel during carbonation of cementitious systems containing slag cements," in Proceedings of the 3rd International Conference: Fly Ash, Silica Fume, Slag and Natural Pozzolans in Concrete, Trondheim, Norway, 1989.

[4] K. Sisomphon and L. Franke, "Carbonation rates of concretes containing high volume of pozzolanic materials," Cement and Concrete Research, vol. 37, no. 12, pp. 1647-1653, 2007.

[5] V. Rostami, Y. Shao, and A. J. Boyd, "Durability of concrete pipes subjected to combined steam and carbonation curing," Construction and Building Materials, vol. 25, no. 8, pp. 33453355, 2011.

[6] E. Gruyaert, P. Van Den Heede, and N. De Belie, "Carbonation of slag concrete: effect of the cement replacement level and curing on the carbonation coefficient-effect of carbonation on the pore structure," Cement and Concrete Composites, vol. 35, no. 1, pp. 39-48, 2013.

[7] W. P. S. Dias, "Reduction of concrete sorptivity with age through carbonation," Cement and Concrete Research, vol. 30, no. 8, pp. 1255-1261, 2000.

[8] J. M. Chi, R. Huang, and C. C. Yang, "Effects of carbonation on mechanical properties and durability of concrete using accelerated testing method," Journal of Marine Science and Technology, vol. 10, no. 1, pp. 14-20, 2002.

[9] G. Verbeck, "Carbonation of hydrated Portland cement," Cement and Concrete, pp. 17-36, 1958.

[10] C. Alonso, C. Andrade, and J. A. González, "Relation between resistivity and corrosion rate of reinforcements in carbonated mortar made with several cement types," Cement and Concrete Research, vol. 18, no. 5, pp. 687-698, 1988.

[11] D. J. Anstice, C. L. Page, and M. M. Page, "The pore solution phase of carbonated cement pastes," Cement and Concrete Research, vol. 35, no. 2, pp. 377-383, 2005.

[12] F. Bouchaala, C. Payan, V. Garnier, and J. P. Balayssac, "Carbonation assessment in concrete by nonlinear ultrasound," Cement and Concrete Research, vol. 41, no. 5, pp. 557-559, 2011.

[13] J. Prabakar, P. D. Manoharan, and A. Chellappan, "Diffusion characteristics of OPC concrete of various grades under accelerated test conditions," Construction and Building Materials, vol. 24, no. 3, pp. 346-352, 2010.

[14] T. Matschei, B. Lothenbach, and F. P. Glasser, "The AFm phase in Portland cement," Cement and Concrete Research, vol. 37, no. 2, pp. 118-130, 2007.

[15] K. Kobayashi, K. Suzuki, and Y. Uno, "Carbonation of concrete structures and decomposition of CSH," Cement and Concrete Research, vol. 24, no. 1, pp. 55-61, 1994.

[16] X. Shi, L. Fay, M. M. Peterson, and Z. Yang, "Freeze-thaw damage and chemical change of a Portland cement concrete in the presence of diluted deicers," Materials and Structures, vol. 43, no. 7, pp. 933-946, 2010.

[17] A. Delnavaz and A. A. Ramezanianpour, "The assessment of carbonation effect on chloride diffusion in concrete based on artificial neural network model," Magazine of Concrete Research, vol. 64, no. 10, pp. 877-884, 2012.

[18] D. W. S. Ho and R. K. Lewis, "The specification of concrete for reinforcement protection-performance criteria and compliance by strength," Cement and Concrete Research, vol. 18, no. 4, pp. 584-594, 1988.
[19] B. Reddy, G. K. Glass, P. J. Lim, and N. R. Buenfeld, "On the corrosion risk presented by chloride bound in concrete," Cement and Concrete Composites, vol. 24, no. 1, pp. 1-5, 2002.

[20] A. Neville, "Chloride attack of reinforced concrete: an overview," Materials and Structures, vol. 28, no. 2, pp. 63-70, 1995.

[21] J. Tritthart, "Chloride binding in cement II. The influence of the hydroxide concentration in the pore solution of hardened cement paste on chloride binding," Cement and Concrete Research, vol. 19, no. 5, pp. 683-691, 1989.

[22] A. A. Ramezanianpour, S. A. Ghahari, and M. Esmaeili, "Effect of combined carbonation and chloride ion ingress by an accelerated test method on microscopic and mechanical properties of concrete," Construction and Building Materials, vol. 58, pp. 138-146, 2014.

[23] I.-S. Yoon, "Deterioration of concrete due to combined reaction of carbonation and chloride penetration: experimental study," Key Engineering Materials, vol. 348-349, pp. 729-732, 2007.

[24] R. Malheiro, A. Camões, R. M. Ferreira, G. Meira, T. Amorim, and R. Rei, "Carbonation front progress in mortars containing fly ash considering the presence of chloride ions," Key Engineering Materials, vol. 634, pp. 214-221, 2015.

[25] ASTM-C150, Standard Specification for Portland Cement, ASTM International, West Conshohocken, Pa, USA, 2012.

[26] ASTM-C1202, Standard Test Method for Electrical Indication of Concrete's Ability to Resist Chloride Ion Penetration, ASTM International, West Conshohocken, Pa, USA, 2012.

[27] Y. Shao, V. Rostami, Z. He, and A. Boyd, "Accelerated carbonation of portland limestone cement," Journal of Materials in Civil Engineering, vol. 26, no. 1, pp. 117-124, 2014.

[28] V. Rostami, Y. Shao, A. J. Boyd, and Z. He, "Microstructure of cement paste subject to early carbonation curing," Cement and Concrete Research, vol. 42, no. 1, pp. 186-193, 2012.

[29] G. Xomeritakis, C.-Y. Tsai, and C. J. Brinker, "Microporous sol-gel derived aminosilicate membrane for enhanced carbon dioxide separation," Separation and Purification Technology, vol. 42, no. 3, pp. 249-257, 2005.

[30] Florida Department of Transportation, "Florida method of test for concrete resistivity as an electrical indicator of its permeability," Tech. Rep. FM-5-578, Florida Department of Transportation, Tallahassee, Fla, USA, 2004.

[31] BS-EN-12390-8, Testing Hardened Concrete. Depth of Penetration of Water under Pressure, British Standards Institution, London, UK, 2009.

[32] BS-EN-480-5, Admixtures for Concrete, Mortar and Grout. Test Methods. Determination of Capillary Absorption, British Standards Institution, 2005.

[33] T. Matschei, B. Lothenbach, and F. P. Glasser, "The role of calcium carbonate in cement hydration," Cement and Concrete Research, vol. 37, no. 4, pp. 551-558, 2007.

[34] J. Hill and J. H. Sharp, "The mineralogy and microstructure of three composite cements with high replacement levels," Cement and Concrete Composites, vol. 24, no. 2, pp. 191-199, 2002.

[35] T. Matschei, R. Skapa, B. Lothenbach, and F. P. Glasser, "The distribution of sulfate in hydrated Portland cement paste," in Proceedings of the 12th International Congress on the Chemistry of Cements, Montreal, Canada, July 2007.

[36] C. Hall, P. Barnes, A. D. Billimore, A. C. Jupe, and $\mathrm{X}$. Turrillas, "Thermal decomposition of ettringite $\mathrm{Ca}_{6}\left[\mathrm{Al}(\mathrm{OH})_{6}\right]_{2}\left(\mathrm{SO}_{4}\right)_{3} \cdot 26 \mathrm{H}_{2} \mathrm{O}$," Journal of the Chemical Society, Faraday Transactions, vol. 92, no. 12, pp. 2125-2129, 1996. 
[37] F. P. Glasser, A. Kindness, and S. A. Stronach, "Stability and solubility relationships in AFm phases: part I. Chloride, sulfate and hydroxide," Cement and Concrete Research, vol. 29, no. 6, pp. 861-866, 1999.

[38] D. Damidot and F. P. Glasser, "Thermodynamic investigation of the $\mathrm{CaO}-\mathrm{Al}_{2} \mathrm{O}_{3}-\mathrm{CaSO}_{4}-\mathrm{H}_{2} \mathrm{O}$ system at $50^{\circ} \mathrm{C}$ and $85^{\circ} \mathrm{C}$," Cement and Concrete Research, vol. 22, no. 6, pp. 1179-1191, 1992.

[39] V. G. Papadakis and S. Tsimas, "Supplementary cementing materials in concrete: part I: efficiency and design," Cement and Concrete Research, vol. 32, no. 10, pp. 1525-1532, 2002.

[40] W. H. Hartt, S. Charvin, and S. K. Lee, Influence of Premeability Reducing and Corrosion Inhibiting Admixtures in Concrete Upon Initiation of Salt Induced Embedded Steel Corrosion, CORROSION 2000, 2000.

[41] A. M. Neville, Properties of Concrete, ELBS with Wesley Longman, London, UK, 4th edition, 1996.

[42] C. S. Poon, S. C. Kou, and L. Lam, "Compressive strength, chloride diffusivity and pore structure of high performance metakaolin and silica fume concrete," Construction and Building Materials, vol. 20, no. 10, pp. 858-865, 2006.

[43] A. Ramezanianpour, S. Ghahari, and A. Khazaei, "Feasibility study on production and sustainability of poly propylene fiber reinforced concrete ties based on a value engineering survey," in Proceedings of the 3rd International Conference on Sustainable Construction Materials and Technologies (SCMT3 '13), pp. 1-8, Coventry University, University of Wisconsin, 2013.

[44] A. A. Ramezanianpour, M. Esmaeili, S. A. Ghahari, and M. H. Najafi, "Laboratory study on the effect of polypropylene fiber on durability, and physical and mechanical characteristic of concrete for application in sleepers," Construction and Building Materials, vol. 44, pp. 411-418, 2013.

[45] M. R. Nokken and R. D. Hooton, "Using pore parameters to estimate permeability or conductivity of concrete," Materials and Structures, vol. 41, no. 1, pp. 1-16, 2008. 

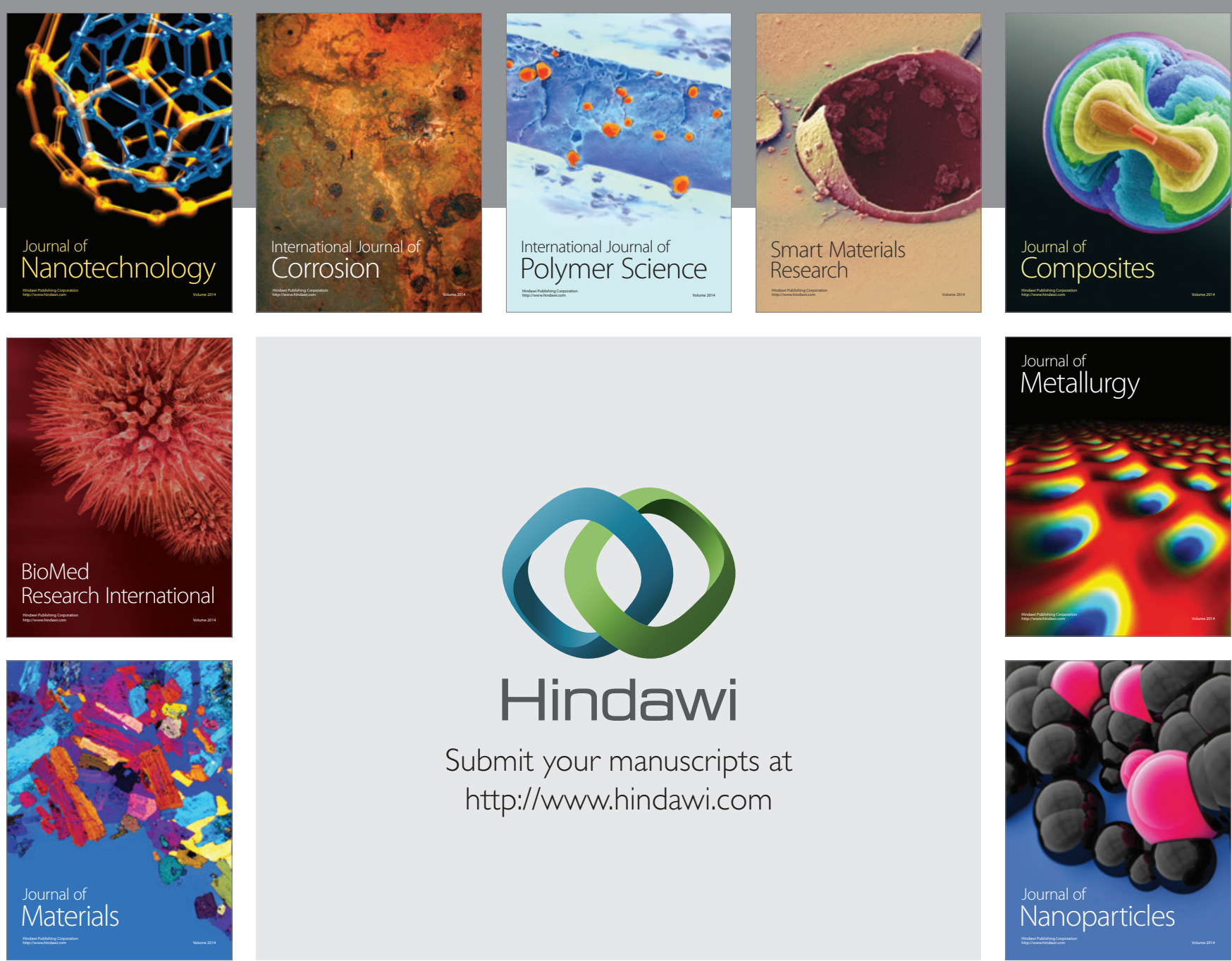

\section{Hindawi}

Submit your manuscripts at

http://www.hindawi.com

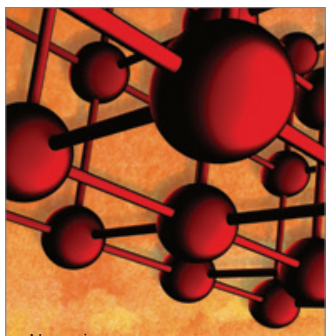

Materials Science and Engineering
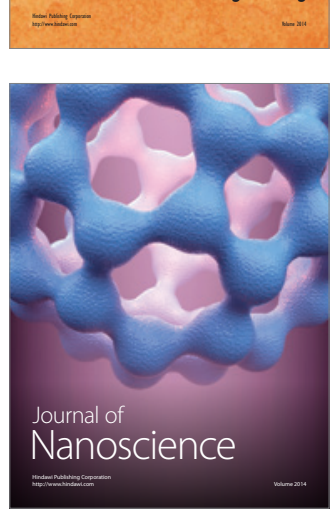
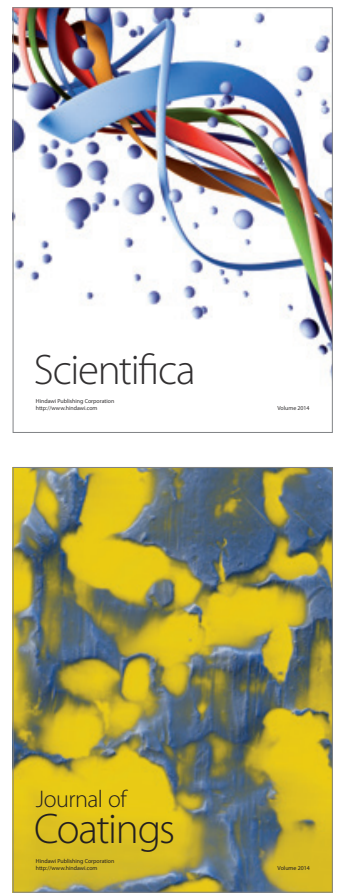
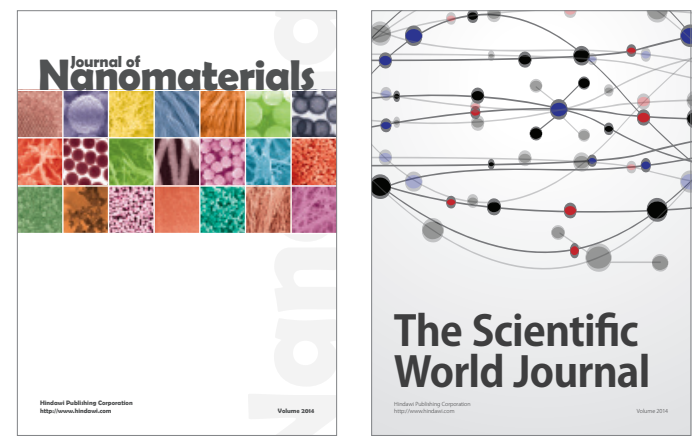

The Scientific World Journal
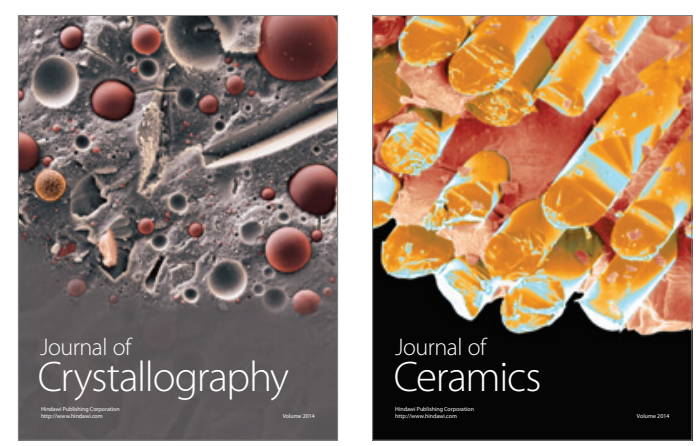
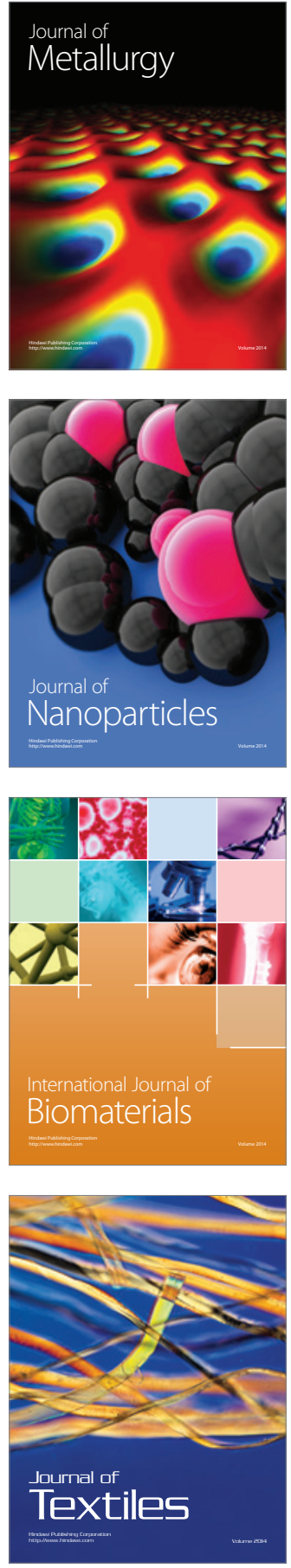